\title{
Learning Habits Shaping Mathematical Literacy: Lens Through the Chronology of Time and Cognitive Processes
}

\author{
Fiki Alghadari \\ Mathematics Education, STKIP Kusuma Negara, fiki_alghadari@stkipkusumanegara.ac.id \\ Audi Yundayani \\ English Education, STKIP Kusuma Negara, audi_yundayani@stkipkusumanegara.ac.id \\ Murat Genç \\ Mathematics Education, Zonguldak Bülent Ecevit Üniversity, muratgenc@beun.edu.tr
}

\begin{abstract}
Mathematical literacy prepares future generations to deal with the challenges of a changing world. However, students' knowledge and abilities are still below the optimal level. This study aims to evaluate how students' learning habits, which are based on the chronology of time and cognitive processes, affect their mathematical literacy. This quantitative research, conducted with the participation of vocational students in West Java, employs an observational approach. The study examines the measurement and structural model up to the second-order levels. The findings revealed that the habit of reviewing had a substantial impact on factors in formulating mathematical models, while the other components were not. Indications of how students adapt information lead to the condition that they do, but not in an ideal way at the logical-operational level. Therefore, learning is insufficient only during school hours due to cognitive capacity considerations besides building an independent learner attitude outside of school.
\end{abstract}

Keywords: cognitive processes, learning habits, mathematical literacy, study time.

\section{ABSTRAK}

Literasi matematis membekali generasi menghadapi perubahan masa. Namum, menurut laporan hasil survei Internasional dan Lembaga Penilaian Pendidikan Indonesia, bekal pengetahuan dan kemampuan yang diwariskan belum optimal. Penelitian ini, fokus pada kebiasaan belajar siswa berdasarkan pertimbangan kronologi waktu dan proses kognitif, bertujuan mengkaji bagaimana dampaknya terhadap literasi matematis. Penelitian kuantitatif ini dilakukan dengan partisiasi siswa sekolah kejuruan di daerah Jawa Barat, menggunakan pendekatan observasional. Penelitian ini menganalisis kesesuaian model pengukuran serta model struktural sampai dengan tingkat kedua. Hasil penelitian menyimpulkan bahwa faktor kebiasaan siswa mereviu konten berdampak signifikan terhadap faktor merumuskan model matematis, sedangkan faktor lainnya tidak signifikan pada tingkat analisis yang sama. Indikasi bagaimana siswa mengadaptasi informasi mengarah kepada kondisi bahwa mereka melakukannya tetapi belum melibatkan berpikir matematis secara optimal di tingkat logika-operasional. Hasil studi ini menjadi alasan mengapa belajar tidak cukup hanya di jadwal sekolah karena pertimbangan kapasitas kognitif yang beroperasi, sedangkan alasan lain adalah menumbuhkan sikap pembelajar mandiri.

Kata Kunci: kebiasaan belajar, literasi matematis, proses kognitif, waktu belajar. 



\section{INTRODUCTION}

The advancement of science has contributed significantlyto the culture of a society in many ways. Susanto (2021) states that science is becoming more comprehensive and in-depth. Moreover, this includes the output of science that makes its dissemination easier and faster than ever before (Widianti, 2021). In response to this situation, a competition ensues, in which the winner demonstrates the superiority or progress of a nation's civilization as evidenced by the existence of traces of life and the ability of its generation to actively participate in the competition for scientific progress (Cecep et al., 2021). As human civilization progresses and evolves, the demands on the capacities of generations and their successors automatically increase (Riski, 2021). Efforts to educate the nation's life must be carried out sustainably, particularly in the field of education (Umbara \& Suryadi, 2019), so that later community members do not simply become "followers" due to a lack of competitiveness and intellectuality (Genc \& Erbas, 2019). Knowledge is typically passed on through educational institutions, ensuring that it maintains its originality while making progress. This heritage will benefit future generations as it will prepare them for the changing circumstances (Mahdiansyah \& Rahmawati, 2014; Pugalee, 1999; Saksono, 2020; Santika, 2021; Steen, Turner, \& Burkhardt, 2007). According to Niss and Jablonka (2020), it is the real agenda of conceptualizing mathematical literacy. As a result, mathematical literacy skills are essential in the twenty-first century (Abidin, Mulyati, \& Yunansah, 2021; Hidayati et al., 2020).

According to OECD (2016), mathematical literacy is defined as the ability to reason, assess, and comprehend problems in a real-world environment and develop decision-making abilities in realworld situations. Because the educational process contributes to the growth and development of literacy skills (Abidin et al., 2021), learning mathematics should also provide students with mathematical literacy skills (Dewantara, 2020; Genç \& Çolakoğlu, 2021; Genc \& Erbas, 2020). However, international surveys from a variety of sources indicate that Indonesian students' mathematical skills remain below average (Alghadari, Herman, \& Prabawanto, 2020; Noor \& Alghadari, 2021), as well as mathematical literacy (Jayanti, Arifin \& Nur, 2020; Yustitia \& Juniarso, 2020). As per the 2018 Program for International Student Assessment (PISA) report, Indonesian students' reading, math, and science scores are all at level 1 out of 6 (Schleicher, 2019). Meanwhile, according to the 2015 Trends in International Mathematics and Science Study (TIMSS) report, the average achievement in content and cognitive mathematics of Indonesian students fell into the low International benchmark category (Mullis et al., 2020). The survey results do not conflict with students' math test scores, even though not all test items are related to mathematical literacy. Furthermore, according to data from the Education Assessment Center in Indonesia, Penilaian Pendidikan Pusat (2019), the average achievement of high school students on a national scale is no more than 39.33 percent, and the average achievement of junior high school students is no more than 46.56 percent, respectively. The knowledge passed down to the following generation appears to be less than optimal as a result. They are also expected to be skilled and capable of interpreting a specific function based on their knowledge throughout their lives and in their jobs (Siregar, Sahirah, \& Harahap, 2020). Saksono (2020) proposes that individuals cultivate literacy, which is described as the habit of thinking, followed by the act of reading and writing, all of which are aimed toward the 
development of something new. During their learning activities, students require appropriate habits for the context of literacy (Ahmadi \& Ibda, 2018). Learning mathematics should engage the mental process to ensure that it is consistent with the subject's essence (Goldenberg, 2014).

In this study, the notion of mathematical literacy culture is formed from personal habits as a component of a person's learning style and pattern (Munfarikhatin, 2019), which is consistent and automatic (Jayanti et al., 2020). They readily receive information, assimilate it, and interact with the learning environment (Yustitia \& Juniarso, 2020). This research is based on the following two phenomena. First, some students prioritize learning activities at school to optimize the function of their cognitive processes, even if they do not always review the material. The second is that some students prefer to review material content outside of the school's learning schedule to adapt to the substance gradually. These two phenomena may coexist based on the chronology of learning time, which is also relevant to cognitive work processes. It's like a flipped classroom model, and according to the results of the study (e.g. Fahmy, Sukestiyarno, \& Mariani, 2019; Herutomo \& Masrianingsih, 2021), the model is effective against mathematical literacy.

This study examined the context of cognitive work activities based on the chronology of their available study hours to absorb information to become knowledge, both during and after the school day. It's really like the concept of a flipped classroom (Fahmy et al., 2019; Yu \& Zhu, 2019; Zheng et al., 2020). This research pertains to Jayanti et al. (2020), who discovered that students are unfamiliar with reviewing learning material prior to face-to-face learning in class. They rarely regurgitate what they have learned following an explanation. The study's outcomes are described in the context of students' habits of studying or relearning content materials outside of planned school meetings, which is referred to as the first context in this study. Habits in this context allow convergent or systematic thinking (McGregor, 2021; Yu \& Zhu, 2019). The second context, which is complementary to the first, is when students are actively engaged in learning, and some are actively engaged in thinking (Arifin, 2020; Genç \& Çolakoğlu, 2021). They are also accustomed to optimizing their thinking capacity (Steen et al., 2007). The habit of cognitive intensification is the second context in which we are now operating on the study schedule in class. The topic related to these two contexts is supported by Goldenberg (2014) that the perfect metaphor for mathematical literacy is about "knowing the literature" gained through regular experience of habitual thinking. The cognitive processes that operate when students are in the classroom are different from when they are outside (Zheng et al., 2020). When studying in class, students usually activate the schemas needed to organize concepts (Goldenberg, 2014), and review content more before or after class (Yu \& Zhu, 2019). Furthermore, Fointuna, Kaluge, \& Fernandez (2020) stated that also helpful in developing mathematical literacy are student behaviors such as reviewing content and broadening their thoughts.

Studying Indonesian students' mathematical literacy is a fascinating topic that has attracted much attention and controversy. According to data from previous relevant studies, mathematical literacy has been linked to learning models (Munfarikhatin, 2019), learning styles (Syawahid \& Putrawangsa, 2017; Yustitia \& Juniarso, 2020), cognitive styles (Genc \& Erbas, 2019; Nurdianasari et al., 2015), PISA question domains (Hidayati et al., 2020), PISA-like tasks (Dewantara, Zulkardi, \& 
Darmawijoyo, 2015), textbook content (Dewantara, 2020; Pakpahan, 2017; Suharyono \& Rosnawati, 2020), and multiple intelligences (Fathani, 2016), factors that contribute to errors, as well as mental habits (Ratnaningsih \& Hidayat, 2021), student achievement category (Hayati \& Kamid, 2019; Sari \& Wijaya, 2017), teacher's perspective (Umbara \& Suryadi, 2019). So far, we have not come across any research linking mathematical literacy to students' learning habits, based on the conceptual framework of cognitive work processes and learning time chronology, that has been published since this writing. Consequently, this study was conducted for the purpose of investigating how students' learning habits impact their mathematical literacy.

\section{METHOD}

An observational technique with a predictive design was used in this quantitative study, which yielded the results. The observed variables were mathematical literacy ability and how students' learning habits were viewed from the perspective of the chronology of time and the participants' cognitive processes. Because mathematical literacy can be obtained through an effort that takes even more time (Genc \& Erbas, 2019), and because it is dependent on a person's cognitive structure, this is an intriguing point to consider (Umbara \& Suryadi, 2019). The purpose of this study is to determine how students' learning habits affect their mathematical literacy abilities.

This research was conducted on vocational school students in Klari district, Karawang Regency, West Java, in 2020. There are seven vocational schools in the district. In all vocational schools in the area, students have been classified into homogeneous groups based on upper secondary school level (K10-K12) and major program. The sampling procedure in this study is to select a vocational school in the district area and a sub-group of students who are respondents. In one group of the selected vocational school, there are four subgroups of students. The selected research sample is a subgroup of students from the first level (K10), which is as many as 30 students.

The information for this study was gathered through a mathematical literacy ability test instrument and a study habit survey questionnaire. The study subjects' habits were characterized by a constant evaluation of the information and an intensification of their ideas. Following the conceptual framework of this study, the chronology of learning time and cognitive processes contrasts the two types of learning. When reviewing material content, it is essential to consider coherence and correspondence, for example, between mathematical notions and the context in which they appear (Steen et al., 2007). Students engage in content review activities that require them to reorganize and reconstruct existing information to incorporate new knowledge (Goldenberg, 2014; Hattan \& Lupo, 2020; Pugalee, 1999). It is possible to think in a convergent or systematic manner if students have learned the following learning habits (McGregor, 2021; Yu \& Zhu, 2019). Alternatively, complexityfocused tasks include: altering information in schemas, balancing new schemes (RossignoliPalomeque, Perez-Hernandez, \& González-Marqués, 2018; Widodo et al., 2019, 2020; Yu \& Zhu, 2019), and creating new schemas (Rossignoli-Palomeque et al., 2018). Students who learn in this manner are more likely to engage in divergent thinking. According to mathematical literacy, following the complicated interaction process (Pugalee, 1999). 
Each item on the mathematical literacy test was measured using an evaluation interval ranging from 0 to 5 . Each item on the learning habits survey was measured using an assessment interval ranging between 0 and 4 . The following two indicators of mathematical literacy were assessed in this study, (1) interpreting context and mathematical concepts and (2) formulating mathematical models regarding phenomena (Mahdiansyah \& Rahmawati, 2014). In addition, the researchers looked at two indicators of learning habits that were measured: (1) reviewing the content and (2) intensifying thoughts. These two indicators represented how students applied the best patterns to establish their consistent learning habits throughout time.

The descriptive statistics and partial least squares-structural equation modeling techniques were employed in this study's data analysis. Using the steps outlined by Hair Jr et al. (2021), the model suitability test for the variables of learning habits and mathematical literacy was evaluated, which included: (1) composite reliability (CR) greater than 0.7 ; (2) comparing outer loading and crossloading; (3) convergent validity at the limit of Average Variance Extracted (AVE) greater than 0.5; (4) discriminant validity based on Fornell-Larcker criteria. In order to examine the structural model for collinearity difficulties, take into account the Variable Importance in the Projection (VIP) values between 0.20 and 5 following the recommendations. Following the determination that all of them meet the evaluation criteria, the following stage determines the significance of the relationship in the overall constellation of relationships.

\section{RESULT AND DISCUSSION}

Table 1 presents the descriptive statistical analysis of the mean and standard deviation of each indicator, which is based on the statistical analysis findings.

Table 1. Descriptive statistical analysis results

\begin{tabular}{lll}
\hline Variable & \multicolumn{2}{l}{ Mean (Standard Deviation) of the indicators } \\
& 1 & 2 \\
\hline Learning habits & $2.345(0.365)$ & $2.527(0.308)$ \\
$\quad$ Review material content & $2.250(0.528)$ & $2.044(0.372)$ \\
$\quad$ Intensify the mind & $2.580(0.394)$ & $2.443(0.368)$ \\
\hline Mathematical literacy & $2.817(1.068)$ & $1.667(1.043)$ \\
$\quad$ Interpreting context & $2.067(0.772)$ & $3.567(1.453)$ \\
$\quad$ Formulate a phenomenon model & $2.167(1.529)$ & $1.167(1.003)$ \\
\hline
\end{tabular}

Table 1 illustrates that the highest average of the learning habits variable is in the context of intensifying the mind, namely the factor of adapting information is 2.580 from a scale of 4 . This factor is the highest average because it starts the literacy process compared to other factors. Hattan \& Lupo (2020) explained that reviewing content to map the interrelated key concepts requires the activation of the knowledge schema to be activated adapted. Table 1 also illustrates that the highest mean of the mathematical literacy variable is in the component of interpreting context, which is the ability to reflect mathematical concepts in the context of 3.567 out of a scale of 5 . It indicates the ability students' knowledge of mathematics has not been used optimally (Yustitia \& Juniarso, 2020), or the knowledge itself is not sufficient as the primary capital of their mathematical literacy (Linuhung, 2015), referring to the average value of the student's literacy ability. Moreover, Mahdiansyah \& 
Rahmawati (2014) argued that students might forget the content of the material that has been studied at the previous level. Then, based on the descriptive statistical analysis, the results of the model suitability analysis are presented in Table 2 .

Table 2. Hasil analisis kesesuaian model pengukuran dan model struktural

\begin{tabular}{|c|c|c|c|c|}
\hline \multirow[t]{2}{*}{ Variabel } & \multicolumn{2}{|c|}{ Outer loading (VIP) of Indicator } & \multirow{2}{*}{$\mathrm{CR}$} & \multirow{2}{*}{ AVE } \\
\hline & 1 & & & \\
\hline Learning habits & $0,970(2,445)$ & $0,900(2,445)$ & 0,934 & 0,876 \\
\hline Reviewing material content & $0,744(1,185)$ & $0,907(1,185)$ & 0,814 & 0,689 \\
\hline Intensifying the mind & $0,775(1,347)$ & $0,938(1,347)$ & 0,850 & 0,740 \\
\hline Mathematical literacy & $0,813(1,783)$ & $0,975(1,783)$ & 0,892 & 0,806 \\
\hline Interpreting context & $0,966(3,814)$ & $0,945(3,814)$ & 0,955 & 0,913 \\
\hline Formulating a phenomenon model & $0,842(1,122)$ & $0,787(1,122)$ & 0,798 & 0,664 \\
\hline
\end{tabular}

Note: The outer loading value is a number that is not in brackets, while the number in brackets is a Variable Importance in the Projection (VIP) value.

The findings of the model's evaluation for the first- and second-order variables of learning habits and mathematical literacy are summarized in Table 2. The first point to note is that all CR values are greater than 0.7 (mathematical literacy $=0.892$, formulating a phenomenon model $=$ 0.798 , interpreting context $=0.955$, learning habits $=0.934$, reviewing materials $=0.814$, intensifying thoughts $=0.850$ ). The second point to note is that all outer loading values are greater than 0.7 , and all outer loading values are greater than the cross-loading values. Moreover, the third point to note is all AVE values more than 0.5 (mathematical literacy $=0.806$, formulating a phenomenon model $=$ 0.664 , interpreting context $=0.913$, learning habits $=0.876$, reviewing material $=0.689$, intensifying thoughts $=0.740)$, and the square root of AVE values such as literacy mathematical $(0.898)$, formulating a phenomenon model (0.815), interpreting context (0.956), learning habits (0.936), reviewing material $(0.830)$, intensifying thoughts $(0.860)$ more than its correlation with other constructs. Last but not least, the results of the collinearity evaluation show that the values are between 1.122 and 3.184, with all values being more than 0.2 and less than 5 .

Table 3. The results of the variable's second-order effect decomposition analysis

\begin{tabular}{lllll}
\hline Independent variable & \multicolumn{4}{c}{ Dependent variable (Mathematical literacy) } \\
(Learning habits) & \multicolumn{2}{c}{ Interpreting context } & \multicolumn{2}{l}{ Formulating a phenomenon model } \\
& $\beta$ & $\mathrm{Cl}$ & $\beta$ & $\mathrm{Cl}$ \\
\hline Reviewing material content & -.367 & $-.800-.089$ & $-.579^{* *}$ & $-1.003-.175$ \\
Intensifying the mind & .045 & $-.384-.680$ & .051 & $-.406-.624$ \\
$R^{2}$ & .117 & & .301 \\
\hline Note-Cl adalah confidence interval, $\beta_{\text {direct }}$ adalah pengaruh langsung. Efek dikalkulasi via bootstrapping procedure (with bias- \\
corrected standard errors) menggunakan 5000 random draws.
\end{tabular}

Table 3 illustrates that: (1) the direct effect of the habit of reviewing material is not significant on interpreting the context $\left(\beta_{\text {direct }}=-0.367, p>0.05\right)$, (2) the direct effect of the habit of reviewing material is significant on formulating the phenomenon model ( $\beta_{\text {direct }}=-0.579, p<0.01, f^{2}=0.298$ ); (3) the direct effect of intensifying thoughts was not significant on interpreting the context $\left(\beta_{\text {direct }}=0.045\right.$, $p>0.05$ ), (4) the direct effect of intensifying thoughts was not significant on formulating the phenomenon model $\left(\beta_{\text {direct }}=0.051, p>0.05\right.$ ). Although the habit of reviewing material has a significant effect on students' ability to formulate phenomena models, the results of the data analysis on the first order of the variables show that the direct influence of learning habits on mathematical literacy skills is not significant ( $\left.\beta_{\text {direct }}=-0.239, p>0.05\right)$. This is not sufficient to explain the findings. 


\section{Mathematical Literacy and the Habit of Reviewing Material Content}

The first-level analysis revealed that the learning habits of students had no discernible effect on their mathematical literacy. Further research revealed that only the students' habit of studying the material substantially affected their capacity to build mathematical models for contextual occurrences, based on the second level component. However, the effect was negative, while other variables had no effect. The habit of reviewing material content, which is a factor in mathematical literacy, is defined by students' habits of paying attention to the correspondence between ideas and contexts have the lowest average value of all learning habits. However, it is complemented by a focus on coherence, which ranks in the high category on average. The ability to build mathematical models is formed by paying attention to content coherence. The correspondence factor contributes to the ability to relate context to concepts or vice versa. It is a good setting for developing mathematical literacy (Jablonka, 2003). This means that systematizing or converging material content during the learning process can affect students' mathematical literacy abilities when it comes to formulating mathematical models about real-world phenomena, for example, by paying attention to the coherence and correspondence of conditions in mathematical phenomena and concepts.

The results of this study are in line with the findings of the study by Yanuarto and Qodariah (2021), which states that students who study independently, accompanied by a relatively high level of initiative, can formulate problems and use mathematical concepts. According to this study, the context of self-study in this study was no different from the time chronology of the activity of reviewing material content carried out by students, which were both carried out outside the class schedule. This study's findings do not conflict with those of Nuurjannah, Hendriana, \& Fitrianna (2018), who discovered that mathematical habits of mind impact mathematical literacy skills. This is because the habit of reviewing material content in learning is also associated with convergent or systematic thinking (McGregor, 2021; Yu \& Zhu, 2019).

As a result of students' habit of revisiting material content related to the concept of repetition, this becomes even more engaging. In fact, according to Trninic (2018), mathematics should be taught in the same way that students learn to swim. The natural learning process and the students' knowledge based on their learning outcomes are complementary, primarily when recurrent but exploratory techniques are used to link them together in a meaningful way. The process of repetition is critical in students' learning of new information (Lomibao \& Ombay, 2017). Through the concept of repetition, one might improve one's capacity to explain, comprehend, and apply particular mathematical concepts. When applied to constructive learning theory, repetition has the purpose of connecting students' experiences with new knowledge in order to stimulate the emergence or enhancement of cognitive structures that allow students to rethink previously held beliefs. This study also revealed that the virtue of learning is insufficient if it is solely dependent on the school schedule. Students should be encouraged to review content in learning materials whether they are in the classroom or outside the classroom so that they become accustomed to reviewing the content of learning materials, such as paying attention to coherence and correspondence, as a form of learning activity, according to the findings of the study. Moreover, to promote mathematical literacy, the style 
of activity of reviewing material content is also appropriate for learning mathematics during the COVID-19 pandemic and the new normal. Settings favor children being able to learn more autonomously in their own homes.

In contrast with the findings of this study students' habit of revisiting material does not significantly impact their ability to interpret the context and mathematical concepts. The analysis results that are also related to this are the lowest average value of the student's habit of paying attention to the correspondence between context and concepts. It is also the lowest average value of the student's habit of paying attention to the correspondence between context and concepts. According to Steen et al. (2007), these factors affect students' ability to represent or manipulate concepts in context. Moreover, according to Sumirattana, Makanong, \& Thipkong (2017), mathematical illiteracy is not the result of a lack of material substance but rather learning methodologies disconnected from real-life situations or personal experience. Throughout this part, emphasis is placed on students' strategies for examining knowledge that assists them in creating their experiences, such as how to detail or transfer the characteristics of a domain from context to mathematical ideas or vice versa. According to Pugalee (1999), the process of detailing or mapping is a communication activity that helps people clarify, interpret, refine, and consolidate their thoughts by promoting associations between informal and intuitive ideas in mathematics in the realm of abstract language, symbolism, and multiple representations in the realm of mathematics. If this is the case, the learning method demonstrates the depth of analysis at the coherence stage, matching reality to correspondence. A connection exists between the learning method and the other components examined in this study, namely the factor that intensifies the mind. Students are interpreting schemas, which are already ingrained in their mental structures, and it is essential to notice that this is not the case.

\section{Habits of Intensifying Thought and Mathematical Literacy}

There is no statistically significant relationship between mathematical literacy and either of the two criteria that fall into the category of intensifying thoughts. Firstly, the impact of the composition of students' habits on modifying the information in the schema and balancing the new schema is not essential in terms of perceiving the context and mathematical concepts, as shown in the previous section. First and foremost, the impact of the composition of students' habits on modifying information in the schema and balancing the new schema is insignificant compared to the component of developing a mathematical model of the phenomena. Furthermore, the average of the lowest measurement results on the habit of increasing the mind is derived from balancing the new scheme, which is the factor of balancing the new scheme. The average trend in strengthening the mind from activating the plan to balancing the new scheme is decreasing.

The model or schema structure generated by students themselves due to adapting information is known as context interpretation of mathematical concepts. The act of correcting and balancing the information included in the schema, on the other hand, culminates in the building of a mental structure (Yu \& Zhu, 2019). There are several steps in this process, including activating, integrating, and refining knowledge and recognizing and correcting misunderstandings, which all contribute to the development of conditional knowledge (Hattan \& Lupo, 2020). Furthermore, according to Gellert, 
Jablonka, and Keitel (2013), the "functional organ" that appears in adaptation to the environment is a mathematical way of thinking at the logical-operational level. At that level, the mode of thinking is understood as an extension of common sense and original intuitive interpretation. The "functional organ" is a mathematical way of thinking at the logical-operational level. According to Sumirattana et al. (2017), one of the factors contributing to mathematical illiteracy is that mathematics has not been connected to real-life situations or personal experiences.

In some cases, when students adapt knowledge that is not ideal at the logic-operational level, mathematical thinking will likely occur. While students may learn how to increase their ideas, likely, their schemas are not yet comprehensive and sturdy enough, despite their mastery of the technique. Even now, there is still a chasm or a chasm between informal knowledge and formal mathematical knowledge. Furthermore, developing a mathematical model of social phenomena makes it possible to recognize mathematical structures in different contexts. Applying mathematical concepts and techniques to use in a wide range of situations assists in developing methodological insights into the process of mathematical modeling. While Gellert et al. (2013) found no evidence that students' habitual thinking was a significant factor in developing these abilities, they asserted that the literacy process of students encounters common sense conflicts when applying mathematical structures to social phenomena. It either obtains them through other techniques or cannot "see" mathematical structures in contexts where they are present.

\section{Research Limitations and Further Study}

Researchers are not concerned about the small number of participants in this study because the goal is to generalize its findings. Furthermore, this research is also notable because it has the potential to result in a more significant hypothesis rejection. Suppose the research hypothesis is accepted despite the relatively small sample size. In that case, it is a finding that adheres to the standards for more reflective features of the sample, not a finding that contradicts the specifications. The thought-intensifying component, on the other hand, has not been found to have any effect on students' learning habits, according to this research, although it can also be viewed as a necessity for the amount of learning time available, this is because working memory operations involve a relatively large cognitive load as a result of the evolution of imperfect domain-specific knowledge, which is characterized by students' low mathematical abilities. Specifically, Sweller (2020) asserts that the function of working memory when processing new information is extremely limited because it is only capable of remembering no more than seven elements, can only process no more than 2-4 components of information, and is only capable of processing information at the same time, or the so-called element interactivity operation, for a maximum of approximately 20 seconds at a time. This is a potentially useful resource whose impact on mathematical literacy has not yet been determined; therefore, it is worth investigating further. It also serves as a limitation of this study because the research instrument utilized does not provide sufficient information about how students intensify their thoughts, how their cognitive processes operate, and how their cognitive resources and loads are distributed among themselves. The concept of these factors is one of the recommendations made by this study. It is open to a future investigation because, at its core, as stated by Goldenberg (2014), 
learning mathematics requires reasoning skills. According to the findings of Genc and Erbas (2019), one of the notions of mathematical literacy is the ability to find answers to every problem by using one's reasoning skills. Furthermore, it is highlighted that the inclination to conduct in a way that is reflective of intellectual or intelligent thinking is created by the habit of mind (Ratnaningsih \& Hidayat, 2021).

\section{CONCLUSION}

Based on the study's findings, it was determined that the impact of students' learning habits on their literacy ability was not statistically significant. Following additional investigation, it was discovered that a habitual element in studying material content has a substantial impact on factors in constructing mathematical models concerning contextual phenomena of mathematical literacy. In contrast, there is no statistically significant impact on any of the other components at the same level of analysis. Furthermore, according to the findings of this study, the habit of reviewing information is the component that contributes to the ability to develop mathematical models of social processes by paying attention to coherence and correspondence. Students must examine mathematical concepts in context and create their cognitive schemas at the logical-operational level to be successful in their learning approaches. This finding is notably well-suited for use as a guideline for fostering a mathematical literacy culture, which can be established through habituation to learning before or after school meetings. This concept is typically met during the flipped classroom model, which forces students to analyze the coherence and correspondence between mathematical concepts and their context to eventually reorganize and reconstruct it as new knowledge. The findings of this study also explain why learning is insufficient if it is just dependent on the school schedule, with one of the reasons being the available cognitive capacity.

\section{REFERENCES}

Abidin, Y., Mulyati, T., \& Yunansah, H. (2021). Pembelajaran Literasi: Strategi Meningkatkan Kemampuan Literasi Matematika, Sains, Membaca, dan Menulis. Bumi Aksara.

Ahmadi, F., \& Ibda, H. (2018). Media literasi sekolah: Teori dan praktik. CV. Pilar Nusantara.

Alghadari, F., Herman, T., \& Prabawanto, S. (2020). Factors Affecting Senior High School Students to Solve Three-Dimensional Geometry Problems. International Electronic Journal of Mathematics Education, 15(3), em0590. https://doi.org/10.29333/iejme/8234

Arifin, M. (2020). Learning Management System (LMS) Berbasis Android Era Revolusi Industri 4.0 Penunjang Creative Thinking Skill Mathematics Siswa. ASNA: Jurnal Kependidikan Islam Dan Keagamaan, 2(2), 12-27.

Cecep, H., Widyastuti, A., Subakti, H., Hasibuan, F. A., Sartika, S. H., Ardiana, D. P. Y., Avicenna, A., Salim, N. A., Karwanto, K., Kato, I., \& others. (2021). Dasar-Dasar Ilmu Pendidikan. Yayasan Kita Menulis.

Dewantara, A. H. (2020). Analisis Konten Buku Teks Matematika K-13 Terkait Potensi Pengembangan Literasi Matematis. Didaktika: Jurnal Kependidikan, 13(2), 112-130. https://doi.org/10.30863/didaktika.v13i2.947

Dewantara, A. H., Zulkardi, Z., \& Darmawijoyo, D. (2015). Assessing Seventh Graders' Mathematical Literacy in Solving PISA-Like Tasks. Indonesian Mathematical Society Journal on Mathematics Education, 6(2), 39-49. https://doi.org/10.22342/jme.6.2.2163.117-128

Fahmy, A. F. R., Sukestiyarno, S., \& Mariani, S. (2019). Mathematical literacy based on student's self-regulated learning by flipped classroom with whatsapp module. Unnes Journal of Mathematics Education Research, 8(2), 125-132.

Fathani, A. H. (2016). Pengembangan literasi matematika sekolah dalam perspektif multiple intelligences. Edu Sains: Jurnal Pendidikan Sains Dan Matematika, 4(2). 
https://doi.org/10.23971/eds.v4i2.524

Fointuna, D. W., Kaluge, A. H., \& Fernandez, A. J. (2020). An analysis of mathematical literacy of state junior high school students in Kupang. Journal of Physics: Conference Series, 1422(1), 012025. https://doi.org/10.1088/1742-6596/1422/1/012025

Gellert, U., Jablonka, E., \& Keitel, C. (2013). Mathematical literacy and common sense in mathematics education. In Sociocultural research on mathematics education (pp. 85-102). Routledge.

Genç, M., \& Çolakoğlu, Ö. M. (2021). Modeling the Effects of Instructional Quality on Mathematical Literacy Performance from the Students' Perspective: PISA 2012 Turkey Sample. Education and Science, 46(206), 1-27. https://doi.org/10.15390/EB.2020.9013

Genc, M., \& Erbas, A. K. (2019). Secondary mathematics teachers' conceptions of mathematical literacy. International Journal of Education in Mathematics, Science and Technology, 7(3), 222237.

Genc, M., \& Erbas, A. K. (2020). Exploring Secondary Mathematics Teachers' Conceptions of the Barriers to Mathematical Literacy Development. International Journal for Mathematics Teaching and Learning, 21(2), 143-173.

Goldenberg, E. P. (2014). "Mathematical literacy": an inadequate metaphor. In Mathematics I\& mathematics education: Searching for common ground (pp. 139-156). Springer.

Hair Jr, J. F., Hult, G. T. M., Ringle, C. M., \& Sarstedt, M. (2021). A primer on partial least squares structural equation modeling (PLS-SEM). Sage publications.

Hattan, C., \& Lupo, S. M. (2020). Rethinking the Role of Knowledge in the Literacy Classroom. Reading Research Quarterly, 55(S1), S283--S298. https://doi.org/10.1002/rrq.350

Hayati, T. R., \& Kamid, K. (2019). Analysis of Mathematical Literacy Processes in High School Students. International Journal of Trends in Mathematics Education Research, 2(3), 116-119. https://doi.org/10.33122/ijtmer.v2i3.70

Herutomo, R. A., \& Masrianingsih, M. (2021). Pembelajaran Flipped Classroom Berpendekatan Matematika Realistik Untuk Mendukung Literasi Matematis Siswa. Jurnal Karya Pendidikan Matematika, 8(2), 45-52. https://doi.org/10.26714/jkpm.8.2.2021.45-52

Hidayati, V. R., Wulandari, N. P., Maulyda, M. A., Erfan, M., \& Rosyidah, A. N. K. (2020). Literasi matematika calon guru sekolah dasar dalam menyelesaikan masalah PISA konten shape and space. JPMI (Jurnal Pembelajaran Matematika Inovatif), 3(3), 185-194.

Jablonka, E. (2003). Mathematical Literacy. In Second International Handbook of Mathematics Education (pp. 75-102). Springer Netherlands. https://doi.org/10.1007/978-94-010-0273-8_4

Jayanti, I., Arifin, N., \& Nur, D. R. (2020). Analisis Faktor Internal dan Eksternal Kesulitan Belajar Matematika Kelas V. SISTEMA: Jurnal Pendidikan, 1(1), 1-7. https://doi.org/10.24903/sjp.v111.602

Linuhung, N. (2015). Penerapan strategi pemecahan masalah wankat-oreovocz dalam peningkatan literasi matematis siswa smp ditinjau dari pengetahuan awal matematis (PAM) siswa. AKSIOMA Journal of Mathematics Education, 4(1), 53-58. https://doi.org/10.24127/ajpm.v4i1.127

Lomibao, L., \& Ombay, S. O. (2017). Does repetition with variation improve students' mathematics conceptual understanding and retention? International Journal of Science and Research, 6(6), 2131-2137. https://doi.org/10.21275/ART20174479

Mahdiansyah, M., \& Rahmawati, R. (2014). Literasi Matematika Siswa Pendidikan Menengah: Analisis Menggunakan Desain Tes Internasional dengan Konteks Indonesia. Jurnal Pendidikan Dan Kebudayaan, 20(4), 452-469. https://doi.org/10.24832/jpnk.v20i4.158

McGregor, C. (2021). "They already know": Bridging rhetorical analysis from social media into the classroom. In J. Dahlman \& T. Winner (Eds.), Beyond the Frontier, Volume III: Innovations in First-Year Composition (pp. 73-88). Cambridge Scholars Publishing.

Mullis, I. V. S., Martin, M. O., Foy, P., Kelly, D. L., \& Fishbein, B. (2020). TIMSS 2019 international results in mathematics and science. In Boston College, TIMSS I\& PIRLS International Study Center. Boston College, TIMSS \& PIRLS International Study Center.

Munfarikhatin, A. (2019). Keefektivan Model PBL Strategi MURDER Terhadap Kemampuan Literasi Matematika Siswa. Musamus Journal of Mathematics Education, 2(1), 32-42. https://doi.org/10.35724/mjme.v2i1.1965

Niss, M., \& Jablonka, E. (2020). Mathematical Literacy. In Encyclopedia of Mathematics Education (pp. 548-553). Springer International Publishing. https://doi.org/10.1007/978-3-030-157890100

Noor, N. A., \& Alghadari, F. (2021). Conceptual technique for comparison figures by geometric thinking in analysis level. Journal for the Mathematics Education and Teaching Practices, 2(1), 
$1-8$.

Nurdianasari, H., Rochmad, R., \& Hartono, H. (2015). Kemampuan Literasi Matematika Siswa Kelas VIII Berdasarkan Gaya Kognitif. UNNES Journal of Mathematics Education Research, 4(2), 76-83.

Nuurjannah, P. E. I., Hendriana, H., \& Fitrianna, A. Y. (2018). Faktor Mathematical Habits of Mind dan Kemampuan Literasi Matematis Siswa SMP di Kabupaten Bandung Barat. Jurnal Mercumatika: Jurnal Penelitian Matematika Dan Pendidikan Matematika, 2(2), 51. https://doi.org/10.26486/jm.v2i2.423

OECD. (2016). PISA 2015 Results (Volume I): Excellence and Equity in Education. OECD Publishing. https://doi.org/10.1787/9789264266490-en

Pakpahan, R. (2017). Faktor-faktor yang memengaruhi capaian literasi matematika siswa Indonesia dalam PISA 2012. Jurnal Pendidikan Dan Kebudayaan, 1(3), 331. https://doi.org/10.24832/jpnk.v1i3.496

Penilaian Pendidikan Pusat. (2019). Penguasaan Materi Ujian Nasional. Pusat Penilaian Pendidikan Kementerian Pendidikan dan Kebudayaan. https://hasilun.puspendik.kemdikbud.go.id/\#2019!smk!capaian_nasional!02\&19\&999!T\&03\&T \&T\&3\&!1!\&

Pugalee, D. K. (1999). Constructing a Model of Mathematical Literacy. The Clearing House: $A$ Journal of Educational Strategies, Issues and Ideas, 73(1), 19-22. https://doi.org/10.1080/00098659909599632

Ratnaningsih, N., \& Hidayat, E. (2021). Error analysis and its causal factors in solving mathematical literacy problems in terms of habits of mind. Journal of Physics: Conference Series, 1764(1), 012104. https://doi.org/10.1088/1742-6596/1764/1/012104

Riski, G. (2021). Pengaruh Minat Baca Pemuda terhadap Tingkat Perkembangan Intelektual Masyarakat. Lifelong Education Journal, 1(2), 118-126. https://doi.org/10.180685/lej.v1i2.26

Rossignoli-Palomeque, T., Perez-Hernandez, E., \& González-Marqués, J. (2018). Brain Training in Children and Adolescents: Is It Scientifically Valid? Frontiers in Psychology, 9, 565. https://doi.org/10.3389/fpsyg.2018.00565

Saksono, H. (2020). Literacy Hub (L-hub): Studi Strategi Literasi Pemerintah Daerah (Studi Kasus di Kota Baubau). Jurnal Kebijakan Pembangunan, 15(1), 105-118. https://doi.org/10.47441/jkp.v15i1.124

Santika, I. G. N. (2021). Grand Desain Kebijakan Strategis Pemerintah Dalam Bidang Pendidikan Untuk Menghadapi Revolusi Industri 4.0. Jurnal Education and Development. https://doi.org/https://doi.org/10.37081/ed.v9i2.2500

Sari, R. H. N., \& Wijaya, A. (2017). Mathematical literacy of senior high school students in Yogyakarta. Jurnal Riset Pendidikan Matematika, 4(1), 100. https://doi.org/10.21831/jrpm.v4i1.10649

Schleicher, A. (2019). PISA 2018: Insights and Interpretations. OECD Publishing.

Siregar, N., Sahirah, R., \& Harahap, A. A. (2020). Konsep Kampus Merdeka Belajar di Era Revolusi Industri 4.0. Fitrah: Journal of Islamic Education, 1(1), 141-157. https://doi.org/10.53802/fitrah.v1i1.13

Steen, L. A., Turner, R., \& Burkhardt, H. (2007). Developing Mathematical Literacy. In Modelling and Applications in Mathematics Education (pp. 285-294). Springer US. https://doi.org/10.1007/978-0-387-29822-1_30

Suharyono, E., \& Rosnawati, R. (2020). Analisis Buku Teks Pelajaran Matematika SMP ditinjau dari Literasi Matematika. Mosharafa: Jurnal Pendidikan Matematika, 9(3), 451-462. https://doi.org/10.31980/mosharafa.v9i3.819

Sumirattana, S., Makanong, A., \& Thipkong, S. (2017). Using realistic mathematics education and the DAPIC problem-solving process to enhance secondary school students' mathematical literacy. Kasetsart Journal of Social Sciences, 38(3), 307-315. https://doi.org/10.1016/j.kjss.2016.06.001

Susanto, A. (2021). Filsafat ilmu: Suatu kajian dalam dimensi ontologis, epistemologis, dan aksiologis. Bumi Aksara.

Sweller, J. (2020). Cognitive load theory and educational technology. Educational Technology Research and Development, 68(1), 1-16. https://doi.org/10.1007/s11423-019-09701-3

Syawahid, M., \& Putrawangsa, S. (2017). Kemampuan literasi matematika siswa SMP ditinjau dari gaya belajar. Beta: Jurnal Tadris Matematika, 10(2), 222-240. https://doi.org/10.20414/betajtm.v10i2.121

Trninic, D. (2018). Instruction, repetition, discovery: restoring the historical educational role of practice. Instructional Science, 46(1), 133-153. https://doi.org/10.1007/s11251-017-9443-z 
Umbara, U., \& Suryadi, D. (2019). Re-Interpretation of Mathematical Literacy Based on the Teacher's Perspective. International Journal of Instruction, 12(4), 789-806. https://doi.org/10.29333/iji.2019.12450a

Widianti, H. (2021). Strategi peningkatan literasi digital dalam pembelajaran matematika (Studi Kasus Peserta Didik SMAN 1 Tanjunganom Nganjuk). Jurnal Lentera: Kajian Keagamaan, Keilmuan Dan Teknologi, 20(1), 101-114.

Widodo, S. A., Istiqomah, I., Leonard, L., Nayazik, A., \& Prahmana, R. C. I. (2019). Formal student thinking in mathematical problem-solving. Journal of Physics: Conference Series, 1188(1), 012087. https://doi.org/10.1088/1742-6596/1188/1/012087

Widodo, S. A., Pangesti, A. D., Istiqomah, I., Kuncoro, K. S., \& Arigiyati, T. A. (2020). Thinking Process of Concrete Student in Solving Two-Dimensional Problems. Jurnal Pendidikan Matematika, 14(2), 117-128. https://doi.org/10.22342/jpm.14.2.9460.117-128

Yanuarto, W. N., \& Qodariah, L. N. (2021). Deskripsi Literasi Matematis Siswa SMP Ditinjau dari Kemandirian Belajar. MATH LOCUS: Jurnal Riset Dan Inovasi Pendidikan Matematika, 1(2), 41-53. https://doi.org/10.31002/mathlocus.v1i2.1070

Yu, Z., \& Zhu, Q. (2019). Schema Theory-Based Flipped Classroom Model Assisted With Technologies. International Journal of Information and Communication Technology Education, 15(2), 31-48. https://doi.org/10.4018/IJICTE.2019040103

Yustitia, V., \& Juniarso, T. (2020). Literasi matematika mahasiswa dengan gaya belajar visual. Malih Peddas (Majalah Ilmiah Pendidikan Dasar), 9(2), 100-109. https://doi.org/10.26877/malihpeddas.v9i2.5044

Zheng, X., Johnson, T. E., \& Zhou, C. (2020). A pilot study examining the impact of collaborative mind mapping strategy in a flipped classroom: learning achievement, self-efficacy, motivation, and students' acceptance. Educational Technology Research and Development, 68(6), 35273545. https://doi.org/10.1007/s11423-020-09868-0 